\title{
Growth, ascorbic acid and iron contents of tissues of young guinea- pigs whose dams received high or low levels of dietary ascorbic acid or Fe during pregnancy and suckling
}

\author{
By C. J. BATES, T. D. COWEN AND HARUMI TSUCHIYA* \\ MRC Dunn Nutritional Laboratory, Downham's Lane, Milton Road, \\ Cambridge CB4 $1 X J$
}

(Received 13 June 1988 - Accepted 23 June 1988)

1. Guinea-pig dams were fed on purified diets containing high $(5 \mathrm{~g} / \mathrm{kg}$ diet plus $1 \mathrm{~g} / 1 \mathrm{drinking}$ water $)$ or moderate $(0.5 \mathrm{~g} / \mathrm{kg}$ diet) levels of ascorbic acid, in combination with high $(1 \mathrm{~g} / \mathrm{kg}$ diet $)$ or moderate $(0.043 \mathrm{~g} / \mathrm{kg}$ diet) levels of iron, during pregnancy and suckling. Their offsprings' diets contained $0.1 \mathrm{~g}$ ascorbic acid $/ \mathrm{kg}$ and $0.04 \mathrm{~g} \mathrm{Fe} / \mathrm{kg}$.

2. High ascorbic acid intake clearly enhanced both tissue ascorbate and $\mathrm{Fe}$ storage in the dams, and high $\mathrm{Fe}$ intake increased both the dams' and the pups' tissue Fe stores.

3. In the animals receiving high Fe intake, a co-existing high ascorbate intake by the dams reduced the growth rate of the offspring, but only during the carly stages of development, not during the later stages of post-weaning growth. All the pups' tissue ascorbate levels fell after weaning, but those born of the dams receiving the high ascorbic acid diets did not fall to levels lower than those of the other pups.

4. Thus, although certain disadvantages to the offspring resulting from very-high ascorbic acid intake by pregnant guinea-pig dams were detected, these did not include permanently increased ascorbate requirements, and hence a progression to scurvy as the pups grew and matured.

The supply of micronutrients during pregnancy is critical. The presence of the fetus generally increases maternal demands, but excessive or imbalanced intakes may lead to fetal impairment at either a morphological or biochemical level. Many women are advised specifically to take iron supplements during pregnancy, and an increasing number also choose to take supplements of water-soluble vitamins, such as vitamin C (L-ascorbic acid). Dietary ascorbic acid is known to influence the absorption of Fe (Cook \& Monson, 1977; Hallberg, 1981) and may also influence its postabsorptive fate (Glover et al. 1972; Smith \& Bidlack 1980 a, b: Milne \& Omaye, 1980; Anon., 1987).

Several groups have reported the existence of a 'conditioning' effect of high intakes of ascorbate in human beings (Cochrane, 1965; Schrauzer \& Rhead, 1973; Tsao \& Salimi, 1984; Omaye et al. 1986). One of these (Cochrane, 1965) refers to an effect on the offspring of pregnant women who had very high intakes, but this is an anecdotal report. There have, in addition, been several recent reports of fetal 'conditioning' by high ascorbate intakes, in pregnant guinea-pigs, apparently leading to increased postnatal ascorbate turnover, and hence increased requirements by the offspring during postnatal development (Samborskaya, 1964; Norkus \& Rosso, 1975; Nandi et al. $1977 a, b$; Basu, 1985). Mature, nonpregnant guinea-pigs seem to be less susceptible to such conditioning effects, since two recent studies (Hornig et al. 1973; Ginter et al. 1982) reported no evidence for increased turnover by mature guinea-pigs with very high ascorbate intakes, while a third (Sorensen et al. 1974) obtained an equivocal result.

The purposes of the present study were, first to determine whether a high intake of ascorbate during pregnancy in guinea-pigs would produce deleterious effects on pregnancy outcome, or on pup growth, or on tissue ascorbate levels of the offspring during the first

* On leave of absence from: Bunka Women's University, 3-22-1 Yoyogi, Shibuya-ku, Tokyo I51, Japan. 
9 weeks of life. The second purpose was to examine the possible effects of a high Fe intake, to test the hypothesis that high-dose Fe might modify the effects of ascorbate supplements, or vice versa.

\section{ANIMALS AND METHODS}

Animals

Female Dunkin Hartley guinea-pigs were acclimatized to purified diets containing two levels each of ascorbic acid and Fe, for several weeks before mating. They were then placed in groups with a boar, until shortly after birth of the pups, when they were transferred to individual cages. On weaning at day 14 post-partum, the dam was removed and the pups were segregated into males and females and transferred to the weaning diet, which had a low content of ascorbic acid $(0 \cdot 1 \mathrm{~g} / \mathrm{kg}$ diet $)$. All animals were weighed every $2 \mathrm{~d}$, and were maintained at constant temperature and a $12 \mathrm{~h}$ light-dark cycle. Shortly after their pups had been weaned, the dams usually were returned to the boar for further reproductive cycles, but a proportion of them were killed at this stage for determination of tissue ascorbate and tissue $\mathrm{Fe}$ in non-pregnant, non-lactating adult females, to confirm that their tissue levels reflected their dietary intakes. Pups were killed at the following three timeintervals post-weaning: 4, 14-16 and 46-53 d.

\section{Diets}

The basic diet mixture contained $(\mathrm{g} / \mathrm{kg})$ : maize starch 201 , acid-washed casein (Irish Dairy Board) 302 , maize oil 74 , sucrose 104 , glucose 74 , cellulose powder 151 , potassium acetate 25 , magnesium oxide 5 , choline chloride 2, inositol 2, thiamin 0.016 , riboflavin 0.016 , pyridoxine hydrochloride $0 \cdot 016$, calcium pantothenate $0 \cdot 040$, nicotinamide $0 \cdot 20$, pteroyl monoglutamate $0 \cdot 010$, biotin 0.0012 , cyanocobalamin $5 \times 10^{-5}$, retinyl acetate 0.0023 , cholecalciferol $7.4 \times 10^{-5}, \alpha$-tocopherol 0.060 , menaphthone 0.010 , Briggs salt mixture (Greenfield et al. 1969) 60. It also contained $0.043 \mathrm{~g} \mathrm{Fe}$ (as ferrous citrate) $/ \mathrm{kg}$, but no added ascorbic acid. Each animal received a small quantity of dried autoclaved hay (also essentially ascorbate-free) each day, to ensure optimal bowel function.

The four maternal diets (A, B, C, D) had the following additions $(\mathrm{g} / \mathrm{kg}$ basic diet): group $\mathrm{A}$, ascorbic acid, 5.0, $\mathrm{Fe}$ as ferrous ammonium sulphate $1.0(1.0 \mathrm{~g} \mathrm{Fe}=7.0 \mathrm{~g}$ ferrous ammonium sulphate); group B, ascorbic acid $0 \cdot 5$, Fe 1.0; group C, ascorbic acid 5.0, Fe 0 ; group $\mathrm{D}$, ascorbic acid $0 \cdot 5, \mathrm{Fe} 0$.

Groups $\mathrm{A}$ and $\mathrm{C}$ also received drinking water containing $1.0 \mathrm{~g}$ ascorbate/1, which was dissolved and renewed daily. All the diets were stored at $4^{\circ}$ until needed, to preserve the ascorbic acid, and were renewed every 3-4 weeks. Portions of the diets were analysed for their ascorbate contents at intervals, using the same high-performance liquid chromatographic (HPLC) assay technique described later for tissue samples. This precaution was essential as a check that the added ascorbate did not deteriorate during storage.

Dams in groups $\mathrm{A}$ and $\mathrm{C}$ received about $0.2 \mathrm{~g}$ ascorbic acid from an unrestricted voluntary intake of about $40 \mathrm{~g}$ diet daily, plus an equal amount from about $200 \mathrm{ml}$ water drunk daily. Their daily ascorbate intake was thus approximately $0 \cdot 4 \mathrm{~g}$. Groups B and D dams obtained approximately $0.02 \mathrm{~g}$ ascorbic acid daily from their diets, i.e. one-twentieth of the intake of those in groups $\mathrm{A}$ and $\mathrm{C}$. Groups $\mathrm{A}$ and B dams received approximately $0.04 \mathrm{~g} \mathrm{Fe} / \mathrm{d}$, compared with approximately $0.0018 \mathrm{~g}$ by those in groups $\mathrm{C}$ and $\mathrm{D}$. The ascorbate content of the pups' weaning diet was $0.1 \mathrm{~g} / \mathrm{kg}$, and the $\mathrm{Fe}$ content was that of the salt mixture, i.e. $0.043 \mathrm{~g} / \mathrm{kg}$. The pups' ascorbate intake was sufficient for normal growth, but not for any major tissue storage. It should be noted that the sucking pups had partial access to their maternal diets for the first 2 weeks of life, before they were transferred 
to the weaning diet. Inter-group differences at this stage could, therefore, be attributable to differences, not only in interuterine history and in composition of maternal milk, but also to some limited direct access to the maternal diets.

Following death by diethyl ether anaesthesia, samples of liver, spleen, adrenals and aqueous humour were removed from the pups or dams for ascorbate and $\mathrm{Fe}$ analyses.

\section{Reduced ascorbate analyses}

The tissues or diet samples were extracted by Potter-Elvehjem homogenization in aqueous metaphosphoric acid $(40 \mathrm{~g} / \mathrm{l})$, centrifuged, and the clear, stablized supernatant fractions stored for up to a few days at $-25^{\circ}$.

Ascorbate analyses were performed by reverse-phase HPLC. A Waters, model $6000 \mathrm{~A}$ solvent delivery system was linked through a Co-Pell ODS precolumn to a Techopak (HPLC Technology Ltd) $\mathrm{C}_{18}$-silica, $250 \times 4.6 \mathrm{~mm}$ column, and thence to an LKB model 2143 electrochemical detector, operating at $+0.6 \mathrm{~V}$. The eluting solvent $(\mathrm{pH} 4.0)$ contained $(\mathrm{mol} / \mathrm{l})$ : hexadecyl trimethyl ammonium bromide 0.01 , sodium acetate $0 \cdot 14$, sodium chloride 0.01 , EDTA $6 \times 10^{-4}$, and it was pumped at $2.0 \mathrm{ml} / \mathrm{min}$. Uric acid, $6 \times 10^{-4} \mathrm{~mol} /$ 1 , was added to the tissue extracts and to the ascorbate standards as an internal standard; quantification was by peak height.

\section{$\mathrm{Fe}$ analyses}

Tissue non-haem-Fe analyses, in liver and spleen samples after storage at $-25^{\circ}$, were performed colorimetrically (Drysdale \& Munro, 1965). Total non-haem-Fe was defined as the fraction of Fe which precipitated from a tissue homogenate in water $(1: 10, \mathrm{w} / \mathrm{v})$, by addition of an equal volume of a saturated aqueous solution of ammonium sulphate. Ferritin- $\mathrm{Fe}$ was defined as the fraction of $\mathrm{Fe}$ remaining in solution, after adjustment of another portion of the homogenate to $\mathrm{pH} 4 \cdot 8$, with dilute acetic acid, followed by centrifugation for $10 \mathrm{~min}$ at $13000 \mathrm{rev} . / \mathrm{min}$ in an MSE Micro Centaur bench centrifuge. Ferritin was then precipitated from the supernatant fraction with an equal volume of saturated aqueous ammonium sulphate solution as described previously. Both the total non-haem-Fe- and ferritin-containing precipitates were collected by centrifugation, and were heated with $2,2^{\prime}$-bipyridyl reagent, to measure their Fe content by the optical density of the Fe-bipyridyl chelate chromophore at $530 \mathrm{~nm}$, using ferric nitrate standards.

Statistical analyses were by Chi-square or by Student's $t$ test, and were verified by twoway analysis of variance. Since numbers of animals per group were uneven, this was done by multiple-regression analysis, using dummy variables, where appropriate. Since it was evident that the body-weights of the animals were significantly influenced both by their sex, and by the numbers of pups in the litter, and that these variables could not, in practice, be precisely matched between the four feed groups, some of the calculations in Table 2 were refined by correction for sex ratios and litter size distributions. This was done by calculating the mean value for each index by sex and by litter size, and then applying appropriate weighting corrections to each measurement, to eliminate the influences of sex and litter size from it, before recalculating the group mean values.

\section{RESULTS}

\section{Observations on dams}

Table 1 shows non-pregnant body-weights, tissue ascorbate, and tissue Fe concentrations of non-pregnant guinea-pig dams. There were no significant differences in body-weights between the diet groups and none of the diets had obvious undesirable effects.

The concentrations of ascorbate in the dams' organs at death were consistent with their 


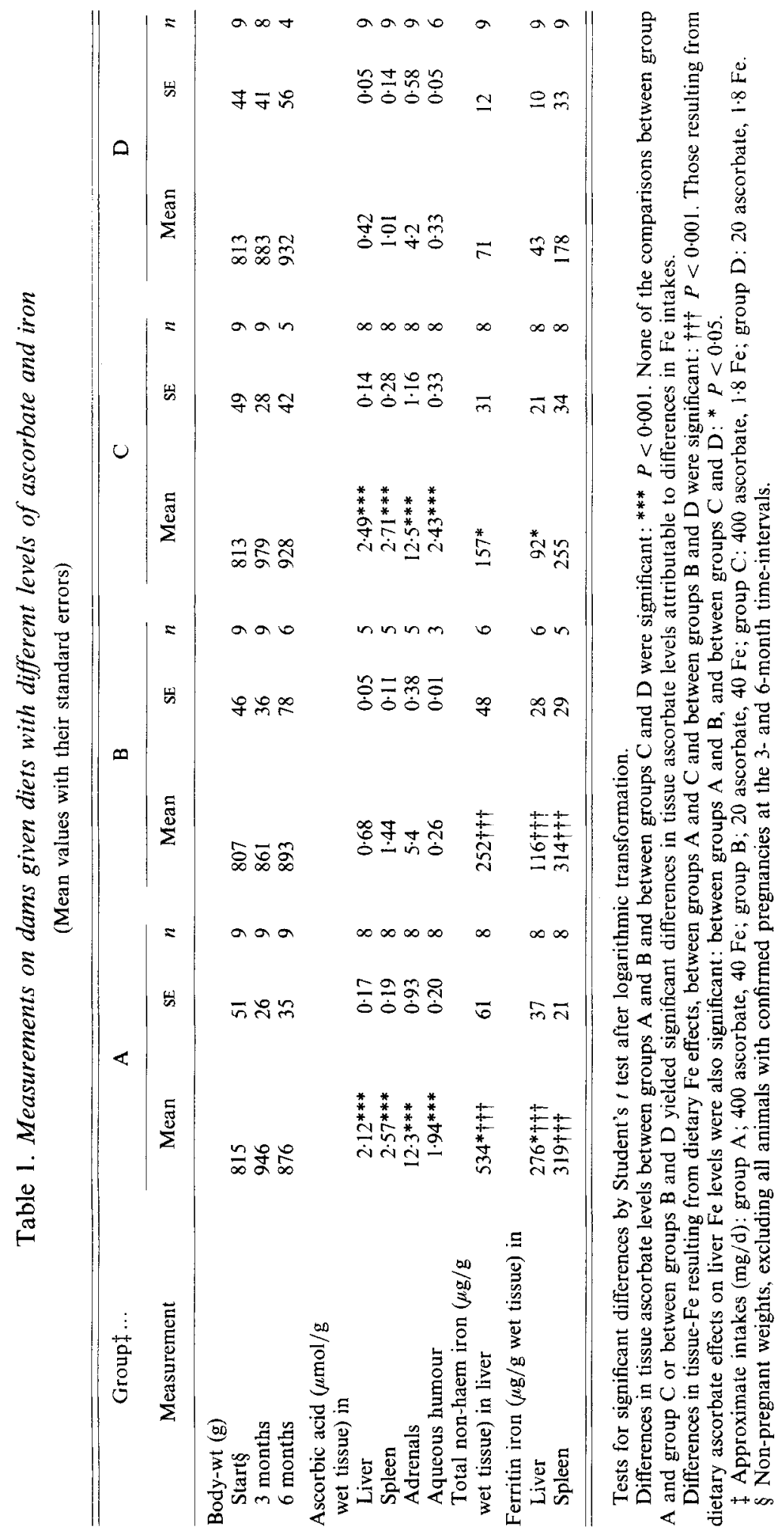




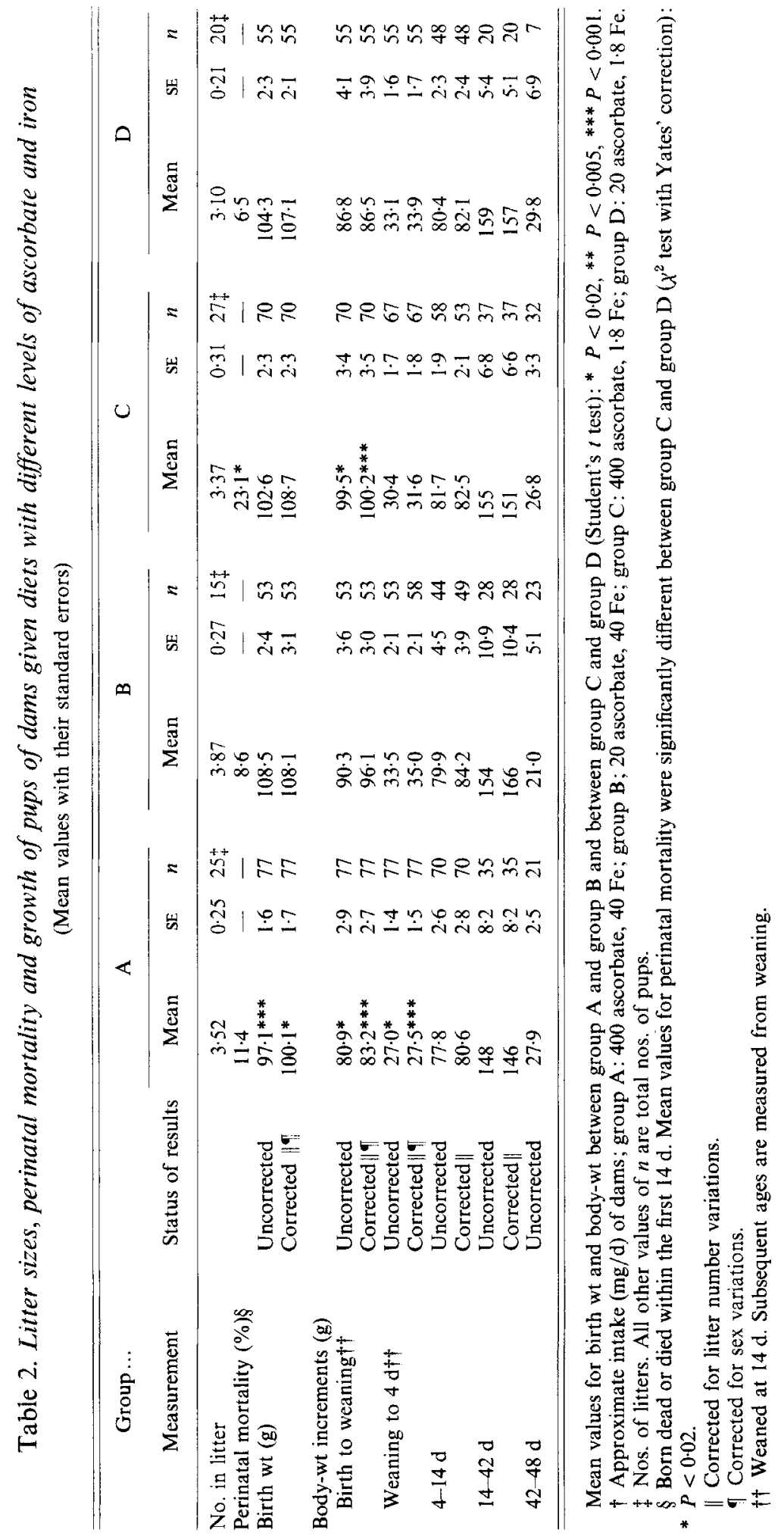


dietary intakes. Those receiving the high ascorbate intake had tissue levels between twoand ten-fold greater than that of those receiving the lower intake. Tissue ascorbate levels were not, however, sensitive to the differences in Fe intake between the low- and highdietary-Fe groups. Hepatic non-haem-Fe clearly reflected $\mathrm{Fe}$ intake by the dams, both total non-haem- and ferritin-Fe being two- to three-fold higher in the high intake groups. There was also a significant effect of ascorbate intake on hepatic total non-haem- and ferritin- $\mathrm{Fe}$; those dams with the higher ascorbate intake accumulated significantly more Fe.

\section{Observations on pups}

Reproductive outcome and growth. Table 2 shows litter sizes, perinatal mortality, birth weights and growth increments of pups until 7 weeks post-weaning (i.e. 9 weeks old).

The numbers of pups per litter, although slightly greater in groups A and B, did not differ significantly between the groups. Perinatal mortality appeared to be considerably greater in group $\mathrm{C}$ than in the other groups, but this observation was complicated by the occurrence of two very-large litters in group $\mathrm{C}$, with seven and eight pups respectively, of which two and six were born dead. If these two litters were excluded, there remained only a non-significant trend towards increased perinatal mortality in groups $\mathrm{A}$ and $\mathrm{C}$ (group $\mathrm{A}$ $10 / 88$ died $v$. group B $5 / 58$ died; $\chi^{2} 0 \cdot 65$, not significant; group C $12 / 76$ died $v$. group D $4 / 62$ died; $\chi^{2} 2 \cdot 07$, not significant). It was thus not possible to attribute increased perinatal mortality necessarily to the high ascorbate intake in group $\mathrm{C}$ independently of the (probably chance) occurrence of large and, therefore, vulnerable litters in this group.

The corrections applied for differences in sex ratios and litter numbers to the group means in Table 1 had a moderate effect on the levels of significance of differences between feed groups, but in no case did they result in a change from significance to non-significance, or vice versa. Therefore, they did not affect the fundamental conclusions about occurrence of significant inter-group differences.

Mean birth weight was significantly lower in group A than in group B (both before and after correction for possible confounding differences in sex ratios and numbers of pups in each litter). Differences in birth-to-weaning weight increases were also significant, but were difficult to interpret, since neither ascorbic acid nor $\mathrm{Fe}$ had a significant influence overall. However, during the first $4 \mathrm{~d}$ post-weaning, group A pups' body-weights suffered a clear disadvantage, whilst of the other three groups, those in group $\mathrm{C}$ grew most rapidly.

After day 4 post-weaning, the inter-group differences in weight gain became nonsignificant. There remained a small trend towards lower values in group A until day 42 , but this had disappeared entirely over the $42-48 \mathrm{~d}$ interval. Clearly any carry-over effects of the maternal diets were greatest at the early stages of pup growth, and did not increase as they grew older, despite the very-low ascorbate content of the weaning diet.

Birth weight and growth from birth to weaning were closely correlated with the number of pups per litter, while the pups were competing for maternal milk, and thereafter the effect of litter numbers rapidly diminished. However, the small pups from large litters did not 'catch up'; instead they followed a parallel growth curve. As expected, growth rate was greater in the male than the female pups, but this reached significance only during the 4-14 d post-weaning time-interval $(P<0.001)$. Both litter size and sex-linked differences were corrected by multiple-regression analysis in calculating the inter-group body-weight differences. Another possible confounding factor could have been season, but an analysis of birth-weight survival and growth rates at different times of year failed to detect any seasonally-related differences.

Tissue ascorbate. Table 3 shows the ascorbate concentrations in each of four tissues of the pups. All but one of the significant inter-group differences occurred during the first two time-periods: particularly at day 4 post-weaning. These differences reflected the high 


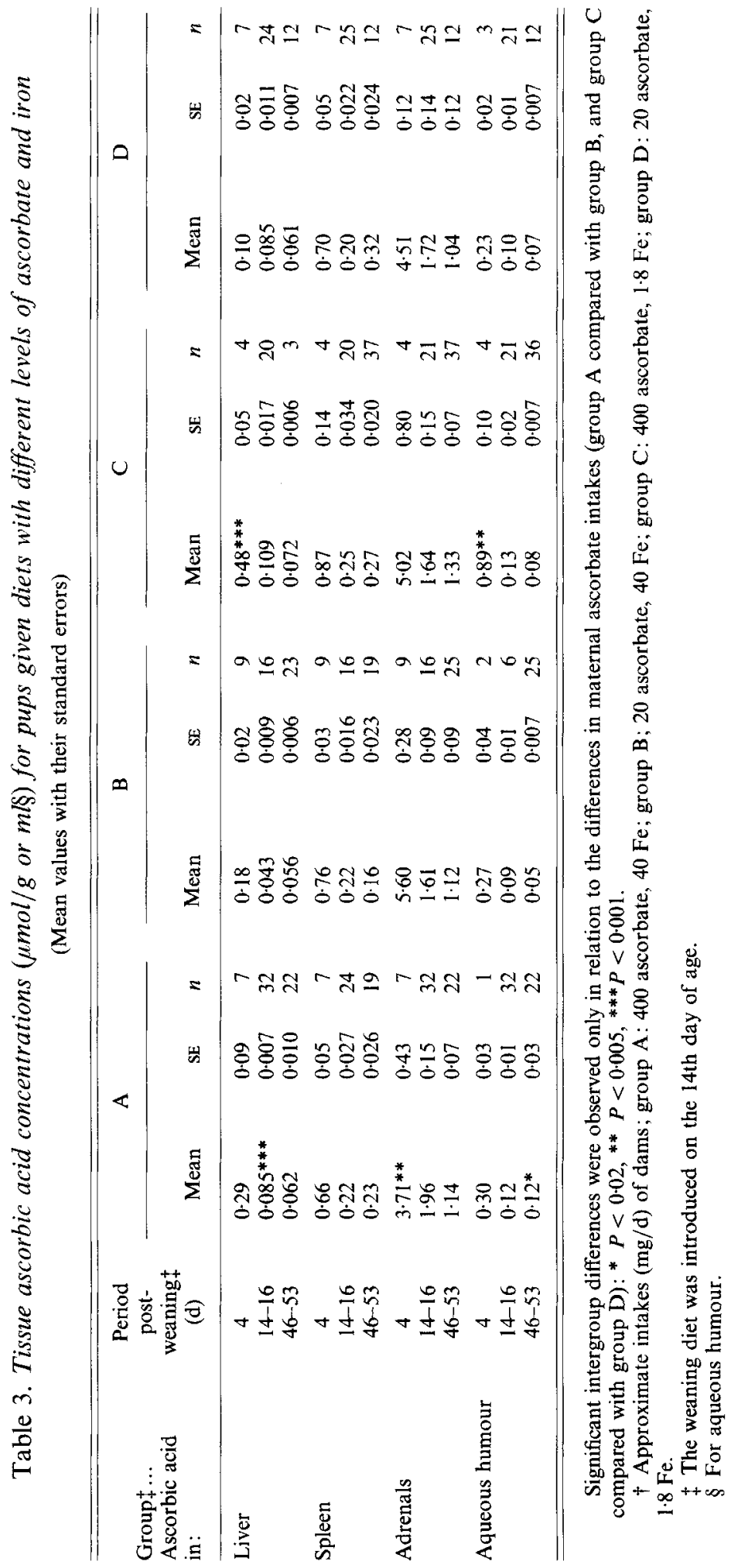




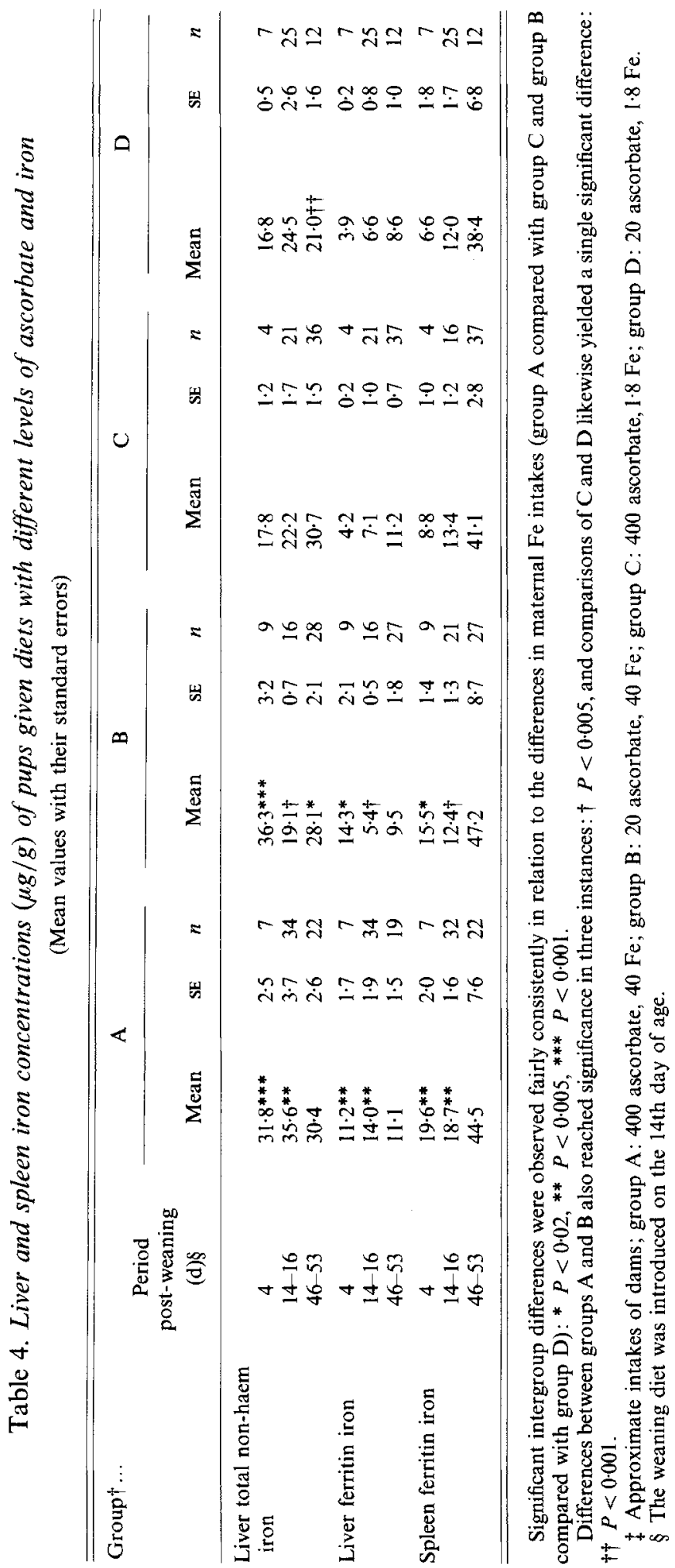


ascorbate intakes in groups $\mathrm{A}$ and $\mathrm{C}$, except for an anomalously-low adrenal ascorbate in group A at day 4 post-weaning. By days 14-16, most of the differences had disappeared, but there was no indication that the concentrations in the tissues of group $\mathrm{A}$ or $\mathrm{C}$ pups reached consistently lower levels than those of groups B and D. Apart from aqueous humour ascorbate, which was relatively high in group $\mathrm{A}$, tissue ascorbate levels at days 46-53 post-weaning were remarkably uniform in all four groups.

Tissue Fe. Table 4 shows total non-haem-Fe concentrations in pups' livers, and ferritinFe concentrations in their livers and spleens. Again, major differences were seen only at the earlier times. Differences attributable to the different Fe contents of the dams' diets were seen more consistently than those attributable to the different ascorbate contents. All these differences diminished as the pups grew older, and by days $46-53$ post-weaning they were small, and significant only for total non-haem-Fe, wherein group D had a lower concentration than groups $\mathrm{B}$ and $\mathrm{C}$.

\section{DISCUSSION}

Justification for ascorbate and $\mathrm{Fe}$ levels in the diets

Pye et al. (1961) showed that $8 \times 10^{-3} \mathrm{~g}$ ascorbate/d was superior, by several criteria, to intakes of 2,4 or $6 \times 10^{-3} \mathrm{~g} / \mathrm{d}$ for pregnant guinea-pigs, but intakes higher than $8 \times 10^{-3}$ $\mathrm{mg} / \mathrm{d}$ were not tested. Rivers \& Devine (1975) observed slightly better long-term reproductive performance in guinea-pig dams fed on approximately $0.08 \mathrm{~g}$ ascorbate/d $(0.1 \mathrm{~g} / \mathrm{kg}$ body-weight per $\mathrm{d})$ than in those fed on approximately $3 \times 10^{-3} \mathrm{~g} / \mathrm{d}\left(4 \times 10^{-3} \mathrm{~g} /\right.$ $\mathrm{kg}$ body-weight per d). Based on these two studies, an intake of $0.02 \mathrm{~g} / \mathrm{d}$ in groups $\mathrm{B}$ and D of the present study appeared fairly generous, but not in the megadose range. The intake of $0.4 \mathrm{~g} / \mathrm{d}$ in groups $\mathrm{A}$ and $\mathrm{C}$ was of the same order as that claimed to produce 'megadose conditioning' effects in three studies (Norkus \& Rosso, 1975; Nandi et al. $1977 a, b$; Basu, 1985). The amount used for the pups' diet, $0.1 \mathrm{~g}$ ascorbate $/ \mathrm{kg}$ diet, providing $1-2 \times 10^{-3}$ $\mathrm{g} / \mathrm{d}$, maintained apparently normal health, and a growth rate similar to that obtained with a commercial diet containing $1.3 \mathrm{~g}$ ascorbate $/ \mathrm{kg}$ (C. J. Bates unpublished observation). However, the weaning diet did not support tissue storage of the vitamin, judging by the low and progressively diminishing amounts in the pups' tissues (Table 3). Any increased turnover should, therefore, have become apparent by a further rate of reduction of tissue ascorbate levels, and probably also of growth rates.

The basal $\mathrm{Fe}$ intake in groups $\mathrm{C}$ and $\mathrm{D}$ dams was equal to that recommended for rodent diets (Greenfield et al. 1969). It supported a moderate increase in reticulo-endothelial $\mathrm{Fe}$ stores in groups $\mathrm{C}$ and $\mathrm{D}$ pups during the first 9 weeks of life (Table 4), which is further evidence for its adequacy. There is little information available about the limits of toxicity, if any, for high intakes of dietary $\mathrm{Fe}$ in guinea-pigs, and the higher intake by groups $\mathrm{A}$ and B dams was, therefore, arbitrarily chosen at twenty-five times the lower intake.

\section{Effects on biochemical and weight indices of dams}

The higher of each of the two levels of ascorbate (diets $\mathrm{A}$ and $\mathrm{C}$ ) and of $\mathrm{Fe}$ (diets $\mathrm{A}$ and B) contributed to large and highly significant increments of ascorbate and Fe, respectively, in the dams' tissues. In addition, the higher ascorbate level enhanced the accumulation of $\mathrm{Fe}$, possibly by enhancing intestinal absorption (Hallberg, 1981). However, neither nutrient at the higher level had any grossly deleterious effect on the dams. In the case of ascorbate, this observation supports the conclusion of Alleva et al. 1976.

\section{Effect on pups' indices}

The early disadvantages for growth and survival of the pups in groups $\mathrm{A}$ and $\mathrm{C}$ receded as the pups aged, in contrast to the prediction that they should have increased if a long-term 
increase in ascorbate turnover had arisen as a result of their dams' megadose intakes. In view of the large numbers of pups studied ( 255 in all four treatment groups at birth, with 120 remaining, after partial culling, by 9 weeks of age), it is probable that any genuine and important inter-group differences would have reached statistical significance.

Tissue ascorbate did not decline faster in groups A and C pups than in groups B and D pups. These observations contrast with those of Norkus \& Rosso (1975), Nandi et al. $(1977 a, b)$ and Basu (1985). The study of Basu (1985) suffered, however, from a lack of precise estimation of ascorbate intake, and that of Nandi et al. $(1977 a, b)$ used an unusual strain of guinea-pigs, and a $630 \mathrm{~g}$ wheat $/ \mathrm{kg}$ diet, which may constitute important differences of design. Norkus \& Rosso (1981), in their second study, found that the increased turnover rate seen in 'conditioned' pups seemed to be confined to the period when their tissue levels remained raised, and the turnover rate appeared to adjust downwards, progressively, as the tissue ascorbate levels fell. This picture is fully consistent with that of the present study, since it does not imply a rebound deficiency.

One important factor in the design of ascorbate-feeding studies is the limited and variable stability of the vitamin in animal diets, and in their drinking-water, especially at room temperature. In the present study it was found to be essential to make analytical checks on the actual ascorbate concentrations present after storage, and to prepare only small batches of diet.

Biochemical or physiological changes have also been reported in two studies of weanling or adult guinea-pigs fed on very-high levels of ascorbate (Maturova et al. 1978; Keith et al. 1981), but these studies were not concerned with the possible occurrence of increased ascorbate turnover. In one study (Nandi et al. 1973) as little as $0.05 \mathrm{~g}$ ascorbate/d proved toxic when the animals received an 'unbalanced' diet deficient in protein, whereas much higher ascorbate intakes were tolerated when a correct balance in the diet was restored. None of these observations conflict with those of the present study, although they do illustrate the complexity of the problem, both in terms of the types of effects that may be seen at different levels of high ascorbate intake, and the importance of the overall dietary balance. It is likely, though not yet proven, that fetal development is one of the moresensitive physiological processes which can be affected by ascorbate overload.

Any extrapolation from the results of guinea-pig studies to conclusions for human nutrition must be made with great caution, especially since the guinea-pig apparently catabolizes some of its ascorbate by pathways which are largely absent in humans (Tolbert, 1985). This fact should, for instance, be recalled when comparing the $\left[{ }^{14} \mathrm{C}\right]$ ascorbateturnover studies of Sorensen et al. (1974), and of Norkus \& Rosso $(1975,1981)$ in guineapigs (which appear to imply a greater fractional rate of catabolism in the groups which have raised tissue levels than in those which have lowered levels), with human $\left[{ }^{14} \mathrm{C}\right]$ ascorbateturnover studies (Baker et al. 1971; Hornig, 1975) which seem to imply a constant fractional turnover rate over a wide range of ascorbate intakes and tissue levels. Further studies to confirm this apparent inter-species difference would be valuable. At the present state of knowledge it appears prudent, however, to avoid the use of prolonged massive ascorbate supplementation during human pregnancy, in the absence of definitely proven benefits. There is a particular need for new communitity studies on the outcome of pregnancy in those women who choose regularly to take large supplementary doses of vitamin $\mathrm{C}$.

The authors are indebted to Miss Ann Schofield for assistance with chemical analyses and to $\mathrm{Dr} \mathrm{T}$. Cole for statistical advice. 


\section{REFERENCES}

Alleva, F. R., Alleva, J. J. \& Balazs, T. (1976). Toxicology and Applied Pharmacology 35, 393-395.

Anon. (1987). Nutrition Reviews 45, 217-218.

Baker, E. M., Hodges, R. E., Hood, J., Sauberlich, H. E., March, S. C. \& Canham, J. E. (1971). American Journal of Clinical Nutrition 24, 444-454.

Basu, T. K. (1985). Canadian Journal of Physiology and Pharmacology 63, 427-430.

Cochrane, W. A. (1965). Canadian Medical Association Journal 83, 893-899.

Cook, J. D. \& Monson, E. R. (1977). American Journal of Clinical Nutrition 30, 235-241.

Drysdale, J. W. \& Munro, H. N. (1965). Biochemical Journal 95, 851-858.

Ginter, E., Drobna, E. \& Ramacsay, L. (1982). International Journal of Vitamin Nutrition Research $\mathbf{5 2}$, $307-311$

Glover, J. M., Jones, P.. R., Greenman, D. A., Hughes, R. E. \& Jacobs, A. (1972). British Journal of Experimental Pathology 53, 295-300.

Greenfield, H., Briggs, G. M., Watson, R. H. J. \& Yudkin, J. (1969). Proceedings of the Nutrition Society 28, 43A.

Hallberg, L. (1981). In Vitamin C; Ascorbic Acid, pp. 49-62. [J. N. Counsell and D. Hornig, editors]. London: Applied Science Publishers.

Hornig, D. (1975). World Review of Nutrition and Dietetics 23, 225-258.

Hornig, D., Weiser, H., Weber, F. \& Wiss, O. (1973). International Journal of Vitamin and Nutrition Research 43 , $28-38$.

Keith, R. E., Libke, K. G. \& Driskell, J. A. (1981). Nutrition Reports International 24, $811-815$.

Maturova, M., Cernoch, M., Walterova, D. \& Santavy, F. (1978). Acta Biologica Medica Germanica 17, 1579-1588.

Milne, D. B. \& Omaye, S. T. (1980). International Journal of Vitamin and Nutrition Research 50, $301-308$.

Nandi, B. K., Majumder, A. K. \& Halder, K. (1977a) International Journal of Vitamin and Nutrition Research 47, 200-205.

Nandi, B. K., Majumder, A. K. \& Halder, K. (1972b) International Journal of Vitamin and Nutrition Research 47 , 265-267.

Nandi, B. K., Majumder, A. K., Subramanian, N. \& Chatterjee, 1. B. (1973). Journal of Nutrition 103, $1688-1695$.

Norkus, E. P. \& Rosso, P. (1975). Annals of the New York Academy of Sciences 258, 401-409.

Norkus, E. P. \& Rosso, P. (1981). Journal of Nutrition 111, 624630.

Omaye, S. T., Skala, J. H. \& Jacob, R. A. (1986). American Journal of Clinical Nutrition 44, $257-264$.

Pye, O. F., Taylor, C. M. \& Fontanares, P. E. (1961). Journal of Nutrition 73, 236-242.

Rivers, J. M. \& Devine, M. M. (1975). Annals of the New York Academy of Sciences 258, 465-482.

Samborskaya, E. P. (1964). Bulletin of Experimental Biology and Medicine, USSR 57, 105-108.

Schrauzer, G. N. \& Rhead, W. J. (1973). International Journal of Vitamin and Nutrition Research 43, $201-211$.

Smith, C. H. \& Bidlack, W. R. (1980 a). Journal of Nutrition 110, 1398-1408.

Smith, C. H. \& Bidlack, W. R. (1980 b). Biochemical Medicine 24, 43-48.

Sorensen, D. I., Devine, M. \& Rivers, J. (1974). Journal of Nutrition 104, 1041-1048.

Tolbert, B. M. (1985). International Journal of Vitamin and Nutritional Research 27, Suppl, 121-138.

Tsao, C. S. \& Salimi, S. L. (1984). Medical Hypotheses 13, 303-310. 